\title{
IMPACT OF DRYING METHODS OVER THE GERMINATIVE POTENTIAL OF CONILON COFFEE OF LATE MATURATION
}

\author{
Sheila Cristina Prucoli Posse ${ }^{1}$, Wagner Nunes Rodrigues ${ }^{2}$, Marcone Comério ${ }^{3}$, \\ Paulo Sérgio Volpi ${ }^{4}$, Abraão Carlos Verdin Filho ${ }^{5}$, Robson Prucoli Posse ${ }^{6}$, \\ Vinicius de Souza Oliveira ${ }^{7}$, Sara Dousseau Arantes ${ }^{8}$
}

(Received: September 25, 2019; accepted: October 23, 2019)

\begin{abstract}
This study aimed to evaluate the effect of different drying methods (regarding temperature and drying time) over the seed moisture and germination of seeds of Coffea canephora, harvested from genotypes of late maturation. For this end, seeds from selected genotypes were harvested and dried using two different methods: drying at $25^{\circ} \mathrm{C}$ with natural circulation of air and drying at $35{ }^{\circ} \mathrm{C}$ with artificial circulation of air. The seeds were evaluated to quantify the loss of moisture content, and their germinative potential was assessed by parameters of germination speed, and the proportion of seedlings with healthy germination originated from them. The results show it is possible to apply different drying methods; using different systems, temperatures and times of exposure; to decrease the moisture content of seeds of C. canephora, from $50 \%$ (freshly harvested seeds from genotypes of late maturation, in July) to under $18 \%$ (dried seeds). Even if the initial stages of the drying process, while the seeds still present high moisture content, are similar for both methods, the method with artificial circulation of air at $35{ }^{\circ} \mathrm{C}$ promotes the drying speed and is able to achieve the lower levels of seed moisture using less than half of the time required by method with natural circulation of air at $25^{\circ} \mathrm{C}$. This faster moisture removal, however, has negative impacts over the germinative potential of the seeds, which are not observed for seeds subjected to the slow natural drying.
\end{abstract}

Index terms: Coffea canephora, germination, propagation, seeds, storage, water content.

\section{INTRODUCTION}

The cultivation of Coffea canephora Pierre ex Froehner has great importance for Brazil, having great historical and socio-economic value, and this primary product is considered one of the most important commodities traded by the country (Conab, 2019). A variety of environmental factors along the cultivation and post-harvest processes can influence the physical-chemical characteristics of coffee, such as water availability, irradiation over fruits, temperature fluctuation, nutritional management, phytosanitary treatment, canopy architecture, harvest method, drying process, storage conditions and preparation (Borém et al., 2008; Flambeau and Yoon, 2018; Hameed et al., 2018; Pimenta et al., 2018). Many of these factors can be managed to preserve the quality of the product, and the post-harvest processes are particularly important in this regard, as they tend to have a direct effect over the final traits of the coffee beans (Coradi et al., 2007).

Coffee harvest tend to put together fruits with different stages of maturation and high levels of moisture, therefore, it is essential to increase homogeneity and decrease humidity, in order to evade unwanted biochemical processes and allow proper storage (Alves et al., 2017; Resende et al., 2010; Siqueira et al., 2017). Coffee drying can be considered one of the most critical postharvest practices, allowing to decrease the water content and the risk of enzymatic fermentation and infestation by microorganisms. This process helps to preserve the nutritional reserves and germinative potential of seeds (Díaz-de-Cerio et al., 2019; Pimenta et al., 2018; Resende et al., 2010).

The drying process can be by natural or artificial methods, but excessively high temperatures should be avoided since exposure to high temperatures can cause physical, chemical, and biological damages to coffee seeds (Reis et al., 2011).

The scientific literature reports a complex relationship between the drying method and biochemical traits of coffee (Borém et al., 2008; Coradi et al., 2007; Corrêa et al., 2006);

\footnotetext{
1,8Instituto Capixaba de Pesquisa, Assistência Técnica e Extensão Rural/Incaper - Rua Afonso Sarlo, 160 - Bento Ferreira 29.052-010 - Vitória-ES - sheilaposse@incaper.es.gov.br, sara.arantes@incaper.es.gov.br

${ }^{2}$ Instituto Capixaba de Pesquisa, Assistência Técnica e Extensão Rural/Incaper - Fazenda Experimental Bananal do Norte Rodovia João Domingo Zago, km 2,5 - 29.323-000 - Cachoeiro de Itapemirim-ES - wagnernunes@outlook.com

3,4,5Instituto Capixaba de Pesquisa, Assistência Técnica e Extensão Rural/Incaper - Fazenda Experimental de Marilândia Rodovia ES-360, Km 1 - Cx. P. 29 - 29.725-000 - Marilândia-ES - marcone.comerio@incaper.es.gov.br, paulovolpi@incaper.es.gov.br, verdin. incaper@gmail.com

${ }^{6}$ Instituto Federal de Educação, Ciência e Tecnologia do Espírito Santo/Ifes - Campus Itapina - Rodovia BR-259, Km 70 - Cx. P. 256 - 29.709-910 - Colatina-ES - robson.posse@ifes.edu.br

${ }^{7}$ Universidade Federal do Espírito Santo/Ufes - Centro Universitário Norte do Espírito Santo - Rodovia BR-101, Km 60 29.932-540 - São Mateus-ES - souzaoliveiravini@gmail.com
} 
however, the majority of the currently available research about this subject was developed with Coffea arabica Lineu. Meanwhile, there is still a lack of research aimed to describe the effect of drying methods over the germinative potential of $C$. canephora. The propagation by seeds in C. canephora, which is a species with a high rate of crossbreeding due to its natural selfincompatibility (Lashermes et al., 1996), is also an excellent method to generate genetic variability and to ampliated the genetic pool available in the cultivated regions. Studies aimed to improve the efficiency of seminal propagation of this species of coffee are important since the recommended cultivars are often formed by a group of seeds originated from genotypes of different ripening cycles (Bragança et al., 2001; Ferrão et al., 2019). Therefore, the required mature seeds may be available during different moments throughout the year, creating the necessity for efficient methods to preserve their germinative potential.

This study aimed to evaluate the effect of different drying methods (regarding temperature and drying time) over the seed moisture and germination of seeds of Coffea canephora, harvested from genotypes of late maturation.

\section{MATERIALS AND METHODS}

\section{Local conditions and drying}

The field from where the seeds were obtained is located in the municipality of Marilândia, in the Northwestern Region of the Espírito Santo State, Southeast Region of Brazil, at the coordinates $19^{\circ} 23^{\prime} 54.5^{\prime \prime} \mathrm{S}$ and $40^{\circ} 32^{\prime} 05.0^{\prime \prime} \mathrm{W}$ (WGS 84) and $229 \mathrm{~m}$ of altitude.

The climate of the region is "Aw", according to the Köppen classification (Kottek et al., 2006), presenting a hot and rainy season between November and February, and a cold and dry season between March and September.

The field is an isolated multiplication site from the Instituto Capixaba de Pesquisa, Assistência Técnica e Extensão Rural (Incaper), where seeds of the genotypes of late maturation of the cultivar "Emcaper 8151 - Robusta Tropical" (National Cultivar Registry \#06382) are produced. All the agronomic practices are done following the current recommendations for C. canephora in Brazil (Ferrão et al., 2019).

From the population, plants with similar aspects of aging, overall growth, vigor, nutritional, and phytosanitary status were sampled. Their fruits were harvested manually in July 2017, when the fruits reached a proportion of maturation of above $80 \%$. Immediately after harvesting, the fruits were semi-pulped and transported. In a laboratory, the fruits were manually processed to obtain fully pulped seeds. The seeds were treated with a solution of sodium hypochlorite $5 \%$ of concentration) for 30 minutes and washed with distilled water (Brasil, 2009).

The processed seeds were separated in homogenous samples and spread over trays in order to form a thin and homogeneous layer. The trays were then randomly selected to be submitted to the different drying methods (regarding methods and exposure times). The natural method subjected the seeds to a natural circulation of air in a climatized room, with the air temperature being monitored and maintained at $25{ }^{\circ} \mathrm{C}\left( \pm 1{ }^{\circ} \mathrm{C}\right)$. The artificial method subjected the seeds to a forced circulation of air in a laboratory oven, with the temperature maintained at $35^{\circ} \mathrm{C}\left( \pm 1{ }^{\circ} \mathrm{C}\right)$.

\section{Test 1: Moisture content}

The effect of the time of exposure to each drying method over the moisture content of the seeds was assessed using a split-plot scheme, with the two drying methods in the parcels (natural and artificial) and 24 periods in the sub-parcels (between 0 and 120 hours). The test followed a completely randomized design using three replicates, and each experimental plot was composed of a sample of $10 \mathrm{~g}$ of seeds.

After each corresponding period being exposed to natural or artificial drying, the moisture content of each sample was evaluated using the standard drying oven method. The samples were weighed on a precision scale $( \pm 0.001 \mathrm{~g})$ and subjected to drying at $105{ }^{\circ} \mathrm{C}\left( \pm 0.5^{\circ} \mathrm{C}\right)$ in a laboratory oven (forced air circulation) until they reach constant weight. The mass loss was used to calculate the moisture content (Brasil, 2009).

\section{Test 2: Germinative potential}

The effect of the final seed moisture content, obtained by each drying method, over the germination was evaluated using a splitplot scheme, with the two drying methods in the parcels (natural and artificial) and eight levels of moisture content in the sub-parcels (between $50 \%$ and $14 \%$ ). The test followed a completely randomized design using four replicates, and each experimental plot was composed of a sample of 50 seeds (200 seeds separated in four replicates of 50 seeds). 
Seed parchment was manually removed before treating the seeds with preventive fungicide. The treated seeds were placed on rolls of germitest paper and irrigated with distilled water, proportional to 2.5 times the weight of the paper. The rolls were stored in germination chambers (biochemical oxygen demand, equipped with fluorescent cold-white lights), using alternating cycles of temperature $\left(30\right.$ to $\left.20^{\circ} \mathrm{C}\right)$ and photoperiod (12 hours of light to 12 hours of dark) (Brasil, 2009).

The seed's germination was monitored daily. The number of seeds that presented initial radicle protrusion was counted as a function of the elapsed time, allowing to calculate the germination speed index (GSI) along the first 30 days (Maguire, 1962). After 30 days, the number of healthy seedlings developed from the initial number of seeds was used to calculate the germination percentage (G\%) (Brasil, 2009).

\section{Statistical analysis}

The data from each test were subjected to analyses of variance and the significance of the interaction between primary factors was verified $(p \leq 0.05)$. In accordance to the significance, the effect of the drying method was studied using the Tukey's test $(p \leq 0.05)$, and the effect of the time of exposure and moisture content were evaluated by regression analyses, testing the fit to different equational models and choosing the best model based on the adjustment, probability, significance and determination coefficients. The analyses were performed using the statistical software GENES (Cruz, 2013).

\section{RESULTS AND DISCUSSION}

A significant interaction was observed between the effects of the methods used for drying and the effects of the time of exposure to the process. Therefore, both factors act together in the determination of the moisture content of the seeds, and the unfolding of this interaction was performed.

For the first hour of drying, there were no differences in moisture content observed between the methods, showing a similar water loss from both artificial and natural methods. This fact may be related to the initial removal of moisture from surface layers, which is facilitated by the proximity and contact with the air to exchange humidity. After this time of exposure, it was possible to observe some differences for the drying methods, but there was a fluctuation between similar moisture and slightly higher moisture for the natural method at $25^{\circ} \mathrm{C}$ up to 6 hours. Past this point of exposure, the differences between the two methods became clear, and the artificial method at $35{ }^{\circ} \mathrm{C}$ promoted lower moisture content (Table 1).

This result shows the possibility to use both methods to successfully remove the humidity from the seeds to low levels of moisture content, even reaching under $18 \%$, which is considered an adequate moisture content for storage for coffee grains (Pimenta et al., 2018; Reis et al., 2011). However, the duration of the process required for reaching lower levels of seed moisture is very different between the two drying methods. For example, the final moisture content after one day of drying using the natural method was $41 \%$ higher than the moisture obtained using the artificial drying with the same time of exposure; and at the end of 3 days of drying, this difference was $155 \%$ higher.

The seed moisture was directly influenced by the time being subjected to the drying methods and presented adjustment to exponential regression models for both natural $\left(\mathrm{R}^{2}=99 \%\right)$ and artificial $\left(\mathrm{R}^{2}=99 \%\right)$ methods (Figure 1). There was a sharp initial loss of humidity, which is followed by a steady decrease in the seed moisture until the process starts to stabilize. This pattern was especially evident along the drying progress of the artificial method from 50\% (harvest) to $10-20 \%$ of seed moisture, which corroborates previously results for coffee drying (Coradi et al., 2014; Corrêa et al., 2006; Pimenta et al., 2018; Siqueira et al., 2017)we aimed to evaluate the influence of the ambient relative humidity $(40,50$ and $60 \%$.

The regression models were similar to describe the decrease of moisture content of seeds. However, the drying rate of each drying method is discernibly different, since the water loss from the artificial method is sharper and faster. This behavior is confirmed by the differences in regression coefficients (Figure 1). The effect of higher temperatures accelerating the drying process has been previously studied for coffee grains and can be explained by the higher thermic energy in the artificial system, which generates a higher difference between the water vapor pressure of air and seeds. This deficit, associated with the increased level of energy and air circulation of the artificial system, facilitates the movement of water molecules, resulting in the faster water loss (Alves et al., 2017; Corrêa et al., 2010, 2006; Siqueira et al., 2016). 
TABLE 1 - Comparison of moisture content of seeds of genotypes of Coffea canephora Pierre ex A. Froehner, of late maturation (harvested in July 2017), after being subjected from 0 to 120 hours of drying by natural or artificial methods (Marilândia, Espírito Santo State, Brazil).

\begin{tabular}{|c|c|c|}
\hline \multirow{2}{*}{$\begin{array}{l}\text { Time being subjected to drying } \\
\text { (h) }\end{array}$} & \multicolumn{2}{|c|}{ Moisture content $(\%)$} \\
\hline & $\begin{array}{l}\text { Natural circulation of air } \\
\text { at } 25^{\circ} \mathrm{C}\end{array}$ & $\begin{array}{l}\text { Artificial circulation of air } \\
\text { at } 35^{\circ} \mathrm{C}\end{array}$ \\
\hline 0 & $49.59 \mathrm{a}$ & $49.59 \mathrm{a}$ \\
\hline $1 / 2$ & $49.37 \mathrm{a}$ & $49.30 \mathrm{a}$ \\
\hline 1 & $49.16 \mathrm{a}$ & $49.15 \mathrm{a}$ \\
\hline $1 \frac{1}{2}$ & $49.43 \mathrm{a}$ & $48.09 \mathrm{~b}$ \\
\hline 2 & $49.43 \mathrm{a}$ & $46.40 \mathrm{~b}$ \\
\hline $2 \frac{1}{2}$ & $47.48 \mathrm{a}$ & $47.36 \mathrm{a}$ \\
\hline 3 & $47.53 \mathrm{a}$ & $48.40 \mathrm{a}$ \\
\hline 4 & $47.63 \mathrm{a}$ & $47.56 \mathrm{a}$ \\
\hline 5 & $48.46 \mathrm{a}$ & $46.90 \mathrm{~b}$ \\
\hline 6 & $44.52 \mathrm{a}$ & $44.09 \mathrm{a}$ \\
\hline 9 & $45.37 \mathrm{a}$ & $43.09 \mathrm{~b}$ \\
\hline 12 & $45.74 \mathrm{a}$ & $40.37 \mathrm{~b}$ \\
\hline 18 & $40.92 \mathrm{a}$ & $34.12 \mathrm{~b}$ \\
\hline 24 & $38.01 \mathrm{a}$ & $26.87 \mathrm{~b}$ \\
\hline 30 & $36.20 \mathrm{a}$ & $22.24 \mathrm{~b}$ \\
\hline 36 & $33.52 \mathrm{a}$ & $16.53 \mathrm{~b}$ \\
\hline 42 & $30.90 \mathrm{a}$ & $13.38 \mathrm{~b}$ \\
\hline 48 & $29.33 \mathrm{a}$ & $11.49 \mathrm{~b}$ \\
\hline 54 & $28.55 \mathrm{a}$ & $10.35 \mathrm{~b}$ \\
\hline 60 & $25.84 \mathrm{a}$ & $9.50 \mathrm{~b}$ \\
\hline 66 & $26.10 \mathrm{a}$ & $10.32 \mathrm{~b}$ \\
\hline 72 & 22.49 a & $8.82 \mathrm{~b}$ \\
\hline 96 & $18.52 \mathrm{a}$ & $7.85 \mathrm{~b}$ \\
\hline 120 & $15.57 \mathrm{a}$ & $7.30 \mathrm{~b}$ \\
\hline
\end{tabular}

Means followed by the same letter in each line do not differ from each other according to Tukey's test, at $5 \%$ of probability.

The germinative potential of the seeds was assessed using eight levels of seed moisture, established based on the drying curves obtained in the previous test, sampling recently harvested seeds $(50 \%)$ and seeds dried using both methods, with increasing times of exposure, until $14 \%$ of seed moisture. There were significant interactions between the effects of the drying methods and the levels of seed moisture for the determination of the germination speed index and percentage. Therefore, the unfolding of this interaction was performed for both variables.

With the single exception of the germination speed index at $44 \%$ moisture (which presented a slight difference), similar patterns of germinative potential were observed regardless of the method used for drying, from $50 \%$ to $23 \%$ of seed moisture. However, drying to seed moisture below this level using the artificial method at $35{ }^{\circ} \mathrm{C}$ caused a decrease of germination speed index and percentage, in contrast with the natural method (Table 2).

The germination speed index as a function of the seed moisture presented fit to a polynomial regression model of $2^{\text {nd }}$ degree for seeds subjected to artificial drying at $35^{\circ} \mathrm{C}\left(\mathrm{R}^{2}=77 \%\right)$. 


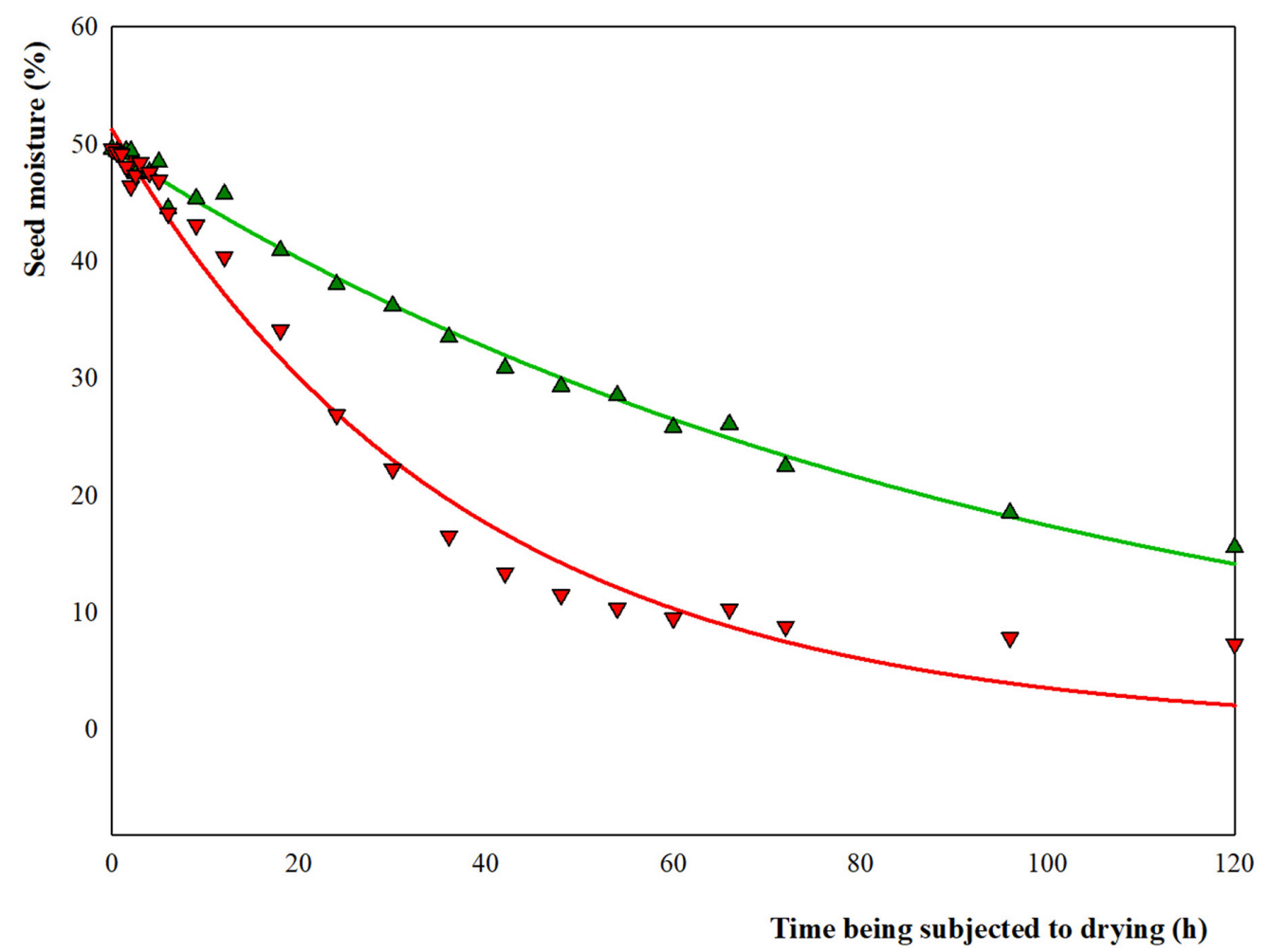

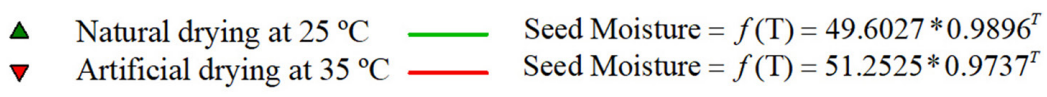

FIGURE 1 - Analyses of moisture content of seeds of genotypes of Coffea canephora Pierre ex A. Froehner, of late maturation (harvested in July 2017), as a function of the time being subjected to drying by natural or artificial methods, from 0 to 120 hours (Marilândia, Espírito Santo State, Brazil).

TABLE 2 - Comparison of germination speed index (GSI) and germination percentage (G\%) of seeds of genotypes of Coffea canephora Pierre ex A. Froehner, of late maturation (harvested in July 2017), after being subjected to drying by natural or artificial methods until different levels of seed moisture (Marilândia, Espírito Santo State, Brazil).

\begin{tabular}{ccccc}
\hline & \multicolumn{3}{c}{ GSI } & \multicolumn{2}{c}{ G\% } \\
\cline { 2 - 5 } Seed moisture (\%) & $\begin{array}{c}\text { Natural circulation of air } \\
\text { at } 25{ }^{\circ} \mathrm{C}\end{array}$ & $\begin{array}{c}\text { Artificial circulation } \\
\text { of air at } 35{ }^{\circ} \mathbf{C}\end{array}$ & $\begin{array}{c}\text { Natural } \\
\text { circulation of air } \\
\text { at } 25{ }^{\circ} \mathrm{C}\end{array}$ & $\begin{array}{c}\text { Artificial circulation of } \\
\text { air at } 35{ }^{\circ} \mathrm{C}\end{array}$ \\
\hline 50 & $5.64 \mathrm{a}$ & $5.64 \mathrm{a}$ & $95.00 \mathrm{a}$ & $95.00 \mathrm{a}$ \\
44 & $5.17 \mathrm{~b}$ & $5.69 \mathrm{a}$ & $94.50 \mathrm{a}$ & $96.50 \mathrm{a}$ \\
37 & $5.24 \mathrm{a}$ & $5.24 \mathrm{a}$ & $95.00 \mathrm{a}$ & $93.50 \mathrm{a}$ \\
32 & $5.27 \mathrm{a}$ & $5.26 \mathrm{a}$ & $93.00 \mathrm{a}$ & $96.50 \mathrm{a}$ \\
27 & $5.09 \mathrm{a}$ & $5.12 \mathrm{a}$ & $96.00 \mathrm{a}$ & $91.50 \mathrm{a}$ \\
23 & $5.14 \mathrm{a}$ & $4.96 \mathrm{a}$ & $96.00 \mathrm{a}$ & $92.00 \mathrm{a}$ \\
17 & $5.50 \mathrm{a}$ & $4.43 \mathrm{~b}$ & $96.00 \mathrm{a}$ & $86.50 \mathrm{~b}$ \\
14 & $4.73 \mathrm{a}$ & $2.18 \mathrm{~b}$ & $93.50 \mathrm{a}$ & $50.00 \mathrm{~b}$ \\
\hline
\end{tabular}

Means followed by the same letter in each line do not differ from each other according to Tukey's test, at $5 \%$ of probability. 
Therefore, a slight increase in the speed index was observed until the maximum point at $41 \%$ of seed moisture (near 8 hours of drying by this method), after which the germination speed index starts to fall sharply. For seeds dried by the natural method at $25^{\circ} \mathrm{C}$, the speed index was not affected (Figure 2A).
The percentage of normal seedlings developed after 30 days of germination followed a similar pattern than the speed index. The proportion of normal seedlings as a function of the seed moisture presented fit to a polynomial regression model of $2^{\text {nd }}$ degree for seeds subjected to artificial drying $\left(35^{\circ} \mathrm{C}\right)\left(\mathrm{R}^{2}=76 \%\right)$.

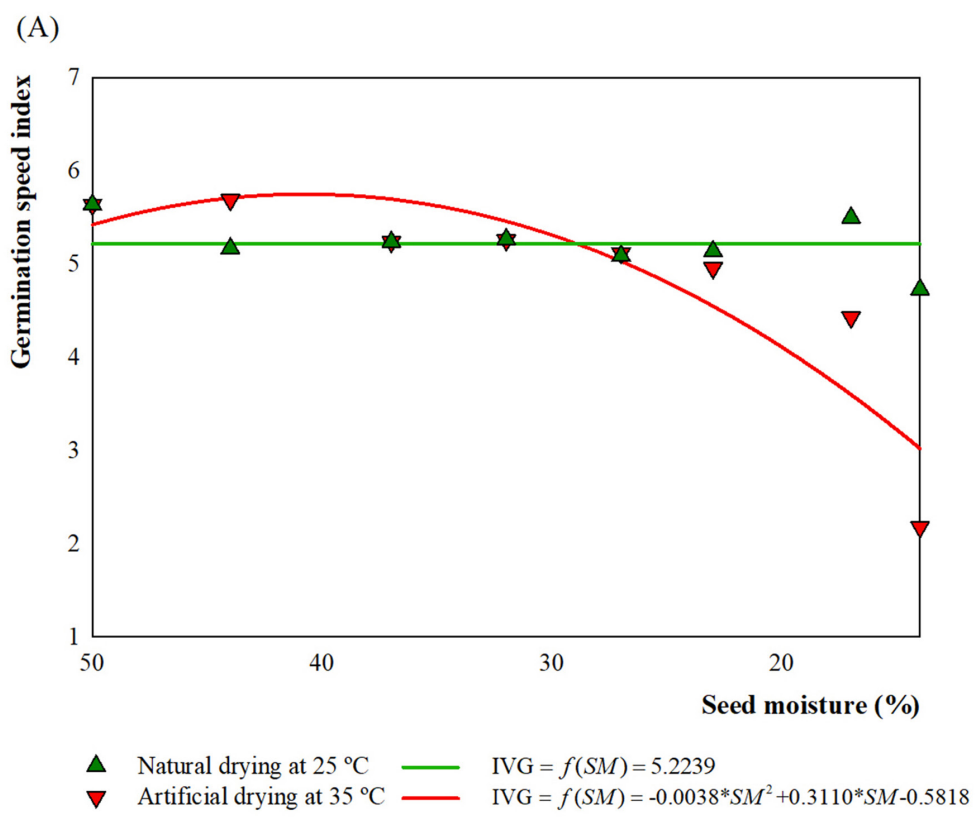

(B)

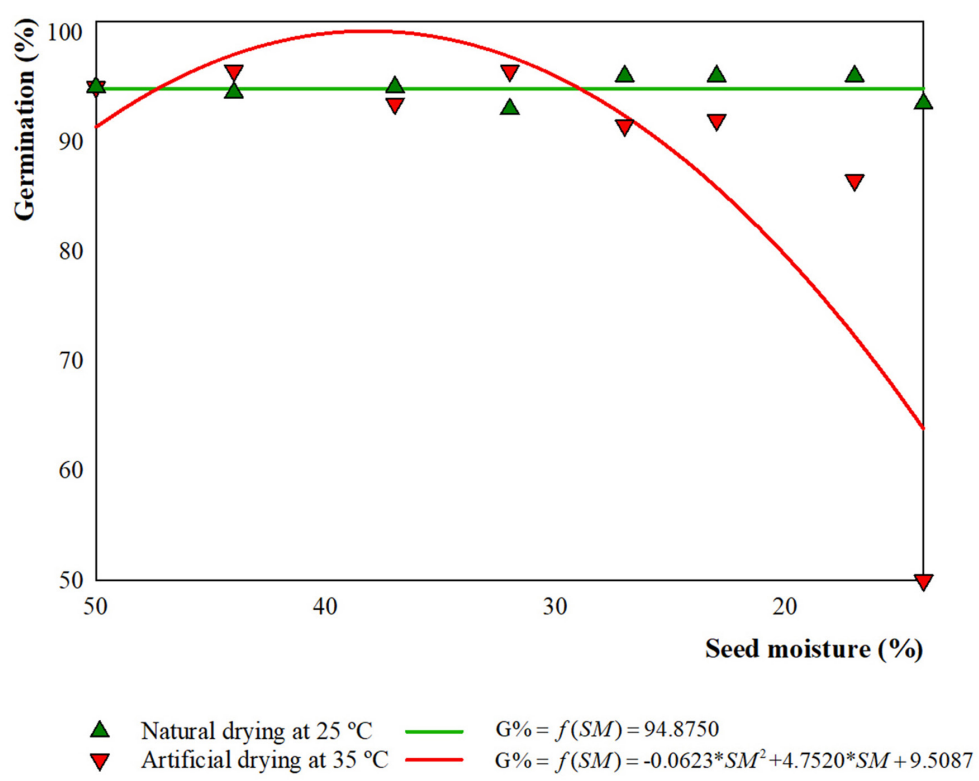

FIGURE 2 - Analyses of germination speed index (A) and germination percentage (B) of seeds of genotypes of Coffea canephora Pierre ex A. Froehner, of late maturation (harvested in July 2017), as a function of the seed moisture after being subjected to drying by natural or artificial methods (Marilândia, Espírito Santo State, Brazil). 
There was a small increase in the germination percentage until a maximum point at $38 \%$ of seed moisture (obtained after near 11 hours of artificial drying), and a sharp decrease after this level. The germination percentage was not affected by the method with the natural circulation of air at $25{ }^{\circ} \mathrm{C}$ (Figure 2B).

The initial gains of germination speed obtained using the artificial drying at $35{ }^{\circ} \mathrm{C}$ are only noticeable for the initial drying stages, as the drying method with higher temperature soon started to cause detrimental effects over the germinative potential. Exposing coffee seeds to high temperatures or maintaining higher temperatures for long periods of time cause physiological damages, resulting in metabolic complications, alteration of the biochemical structure of cells, damage to the endosperm, loss of viability of the embryo, decrease of membrane integrity and, overall, loss of seed quality (Alves et al., 2017; Saath et al., 2012; Taveira et al., 2012).

The effect of the higher temperature affected not only the speed of the germination (Figure 2A) but also the final proportion of seeds able to germinate normally (Figure 2B). Considering the lowest level of seed moisture (14\%) as an example, the number of normal seedlings, after 30 days of germination, obtained from the natural method was $87 \%$ higher than the observed for seeds subjected to artificial drying. There are other scientific reports describing the occurrence of biochemical alterations in coffee seeds due to the exposure to high temperatures (Coradi et al., 2007; Pimenta et al., 2018; Siqueira et al., 2017); and these alterations may be responsible for the modification of the germinative potential observed for seeds treated with the artificial method. It was observed that seeds subjected to this method for longer periods were more prone to a deacceleration or inhibition of the germinative process (Figure 3).

Overall, it is possible to dry the seeds using both natural or artificial methods, but it is important to take the time of exposure and the speed of the water loss into consideration. Both methods were successfully used to remove the initial humidity without causing damages to the germinative potential, and the artificial drying was efficient in order to dry the seeds, requiring considerably less time. However, if it becomes necessary to decrease the moisture content to low levels, in order to enhance the storage, the speedy water loss from the artificial process may negatively affect the germination of the seeds and, therefore, the slow drying achieved by the natural method becomes more suitable.

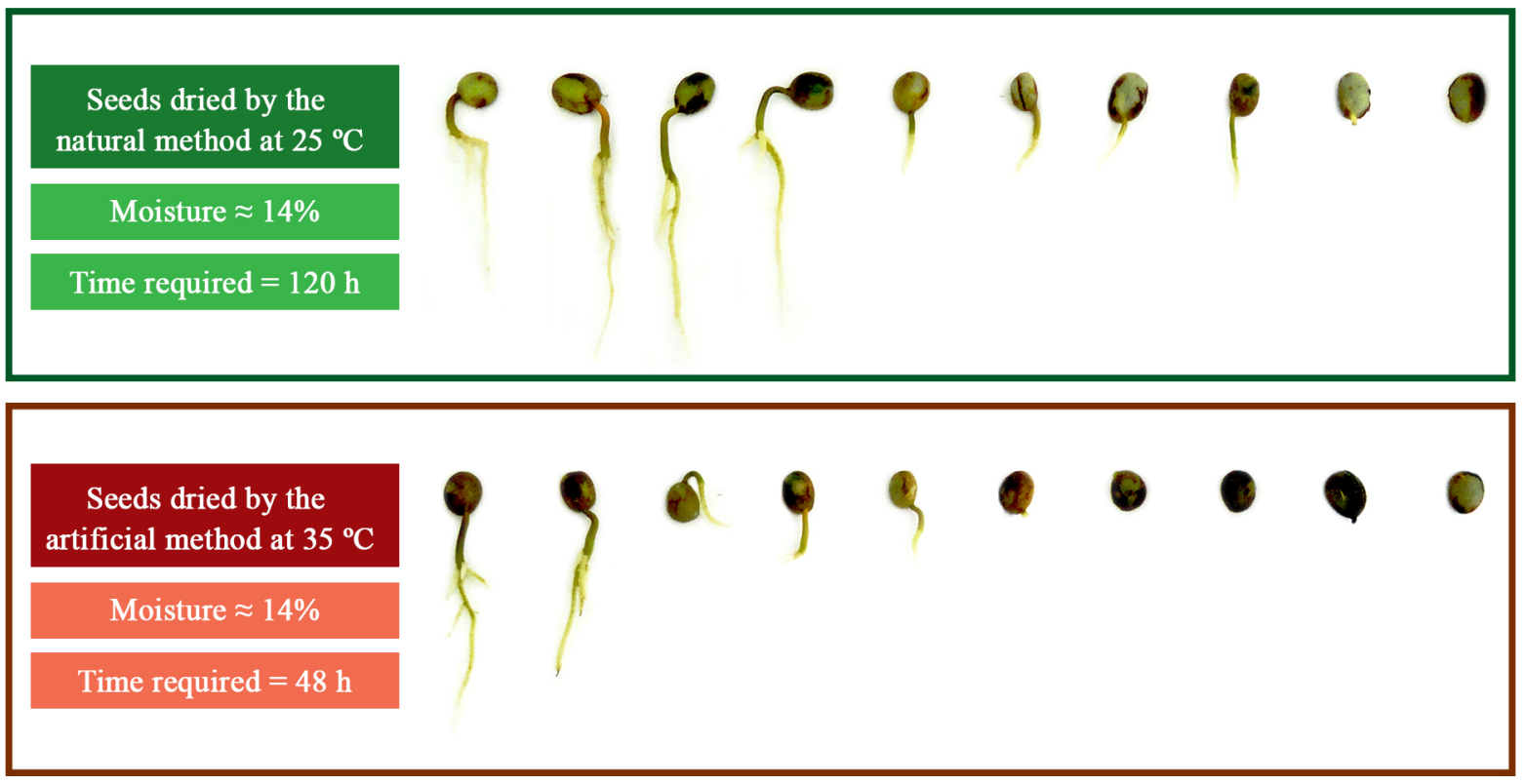

FIGURE 3 - Samples of seeds of genotypes of Coffea canephora Pierre ex A. Froehner, of late maturation (harvested in July 2017), 30 days after being dried (from $50 \%$ to $14 \%$ of moisture content) by natural (120 h of natural circulation of air at $25^{\circ} \mathrm{C}$ ) or artificial $\left(48 \mathrm{~h}\right.$ of forced circulation of air at $\left.35^{\circ} \mathrm{C}\right)$ methods (Marilândia, Espírito Santo State, Brazil). 


\section{CONCLUSION}

It is possible to apply different drying methods; using different systems, temperatures and times of exposure; to decrease the moisture content of seeds of Coffea canephora, from 50\% (freshly harvested seeds from genotypes of late maturation, in July) to under 18\% (dried seeds). Even if the initial stages of the drying process, while the seeds still present high moisture content, are similar for both methods, the method with artificial circulation of air at $35^{\circ} \mathrm{C}$ promotes the drying speed and is able to achieve the lower levels of seed moisture using less than half of the time required by method with natural circulation of air at $25{ }^{\circ} \mathrm{C}$. This faster moisture removal, however, has negative impacts over the germinative potential of the seeds, which are not observed for seeds subjected to the slow natural drying.

\section{ACKNOWLEDGMENTS}

The authors would like to express thanks to the Consórcio Pesquisa Café and Empresa Brasileira de Pesquisa Agropecuária (Embrapa) for their financial support, and to the Instituto Capixaba de Pesquisa, Assistência Técnica e Extensão Rural (Incaper) for providing access to the necessary facilities and tools. The authors would also like to express gratitude to the research fellows Poliana Pratti Valfré and Fernanda Rodrigues Nunes e Silva for providing aid in the execution of this work.

\section{REFERENCES}

ALVES, G. E. et al. Qualidade fisiológica e sensorial do café arábica submetido a diferentes temperaturas e fluxos de ar de secagem. Acta Scientiarum. Agronomy, Maringá, v. 39, n. 2, p. 225-233, 2017.

BORÉM, F. M. et al. Avaliação sensorial do café cereja descascado, armazenado sob atmosfera artificial e convencional. Ciência e Agrotecnologia, Lavras, v. 32, n. 6, p. 1724-1729, 2008.

BRAGANÇA, S. M. et al. Variedades clonais de café Conilon para o Estado do Espirito Santo. Pesquisa Agropecuaria Brasileira, Brasília, v. 36, n. 5, p. 765770, 2001.

BRASIL. Regras para análise de sementes. Brasília: Ministério da Agricultura, Pecuária e Abastecimento. Secretaria de Defesa Agropecuária, 2009. 399p.
CONAB - COMPANHIA NACIONLA DE ABASTECIMENTO. Acompanhamento da safra brasileira: café. Brasília: Conab, 2019. 61p.

CORADI, P. C.; BORÉM, F. M.; REINATO, C. H. Coffee cherries drying process and the influence of environment relative humidity in the mathematical modeling, moisture content, and enthalpy of vaporization. Revista Energia na Agricultura, Botucatú, v. 29, n. 2, p. 148-157, 2014.

CORADI, P. C. et al. Effect of drying and storage conditions on the quality of natural and washed coffee. Coffee Science, Lavras, v. 2, n. 1, p. 38-47, 2007.

CORRÊA, P. C. et al. Modelagem matemática e determinação das propriedades termodinâmicas do café (Coffea arabica L.) durante o processo de secagem. Revista Ceres, Viçosa, v. 57, n. 5, p. 595-601, (2010).

CORRÊA, P. C.; RESENDE, O.; RIBEIRO, D. M. Drying characteristics and kinetics of coffee berry. Revista Brasileira de Produtos Agroindustriais, Campina Grande, v. 8, n. 1, p. 1-10, 2006.

CRUZ, C. D. Genes - software para análise de dados em estatística experimental e em genética quantitativa. Acta Scientiarum. Agronomy, Maringá, v. 35, n. 3, p. 271-276, 2013.

DÍAZ-DE-CERIO, E. et al. Analytical approaches in coffee quality control. In: GRUMEZESCU, A.; HOLBAN, A. M. Caffeinated and cocoa based beverages. Cambridge: Elsevier/Woodhead, 2019. p. 285-336.

FERRÃO, R. G. et al. Conilon coffee. 3. ed. Vitória: Incaper, 2019. 974p.

FLAMBEAU, K. J.; YOON, J. Characterization of raw and roasted fully washed specialty Bourbon cultivar of Coffea arabica from major coffee growing areas in Rwanda. Food Engineering Progress, Gyeonggi, v. 22, n. 2, p. 89-99, 2018.

HAMEED, A. et al. Farm to consumer: factors affecting the organoleptic characteristics of coffee. II: postharvest processing factors. Comprehensive Reviews in Food Science and Food Safety, Chicago, v. 17, n. 5, p. 11841237, 2018.

KOTTEK, M. World map of the Köppen-Geiger climate classification updated. Meteorologische Zeitschrift, Stuttgart, v. 15, n. 3, p. 259-263, 2006. 
LASHERMES, P. et al. Inheritance and genetic mapping of self-incompatibility in Coffea canephora Pierre. Theoretical and Applied Genetics, Stuttgart, v. 93 , n. 3, p. 458-462, 1996.

MAGUIRE, J. D. Speed of germination-aid in selection and evaluation for seedling emergence and vigor. Crop Science, v. 2, n. 1, p. 176-177, 1962.

PIMENTA, C. J.; ANGÉLICO, C. L.; CHALFOUN, S. M. Challengs in coffee quality: cultural, chemical and microbiological aspects. Ciencia e Agrotecnologia, Lavras, v. 42, n. 4, p. 337-349, 2018.

REIS, P. R.; CUNHA, R. L.; CARVALHO, G. R. Café arábica: da pós-colheita ao consumo. Lavras: Epamig, 2011. 734p.

RESENDE, O. Cinética da secagem de clones de café (Coffea canephora Pierre) em terreiro de chão batido. Acta Amazonica, Manaus, v. 40, n. 2, p. 247-255, 2010.
SAATH, R. Alterações na composição química e sensorial de café (Coffea arabica L.) nos processos póscolheita. Revista Energia na Agricultura, Botucatú, v. 27, n. 2, p. 96-112, 2012.

SIQUEIRA, V. C. et al. Drying kinetics of processed natural coffee with high moisture content. Coffee Science, Lavras, v. 12, n. 3, p. 400-409, 2017.

SIQUEIRA, V. C. et al. Drying of hulled naturally processed coffee with high moisture content and its impacts on quality. African Journal of Agricultural Research, Sapele, v. 11, n. 31, p. 2903-2911, 2016.

TAVEIRA, J. H. S. et al. Perfis proteicos e desempenho fisiológico de sementes de café submetidas a diferentes métodos de processamento e secagem. Pesquisa Agropecuaria Brasileira, Brasília, v. 47, n. 10, p. 1511-1517, 2012. 